\title{
Different expectations: a comparative history of structure, experience, and strategic alliances in the U.S. and U.K. poultry sectors, 1920-1990
}

Article

Accepted Version

Godley, A. C. and Hamilton, S. (2020) Different expectations: a comparative history of structure, experience, and strategic alliances in the U.S. and U.K. poultry sectors, 1920-1990. Strategic Entrepreneurship Journal, 14 (1). pp. 89-104. ISSN 1932-4391 doi: https://doi.org/10.1002/sej.1334 Available at https://centaur.reading.ac.uk/82722/

It is advisable to refer to the publisher's version if you intend to cite from the work. See Guidance on citing.

To link to this article DOI: http://dx.doi.org/10.1002/sej.1334

Publisher: Wiley

All outputs in CentAUR are protected by Intellectual Property Rights law, including copyright law. Copyright and IPR is retained by the creators or other copyright holders. Terms and conditions for use of this material are defined in the End User Agreement. 


\section{CentAUR}

Central Archive at the University of Reading

Reading's research outputs online 
Different expectations: A comparative history of structure, experience, and strategic alliances in the U.S. and U.K. poultry sectors, 1920-1990

\author{
Andrew C. Godley \\ Henley Business School, University of Reading \\ HBS 242, Whiteknights \\ Reading RG6 6UD \\ a.c.godley@henley.ac.uk \\ +44 (0) 1183785051
}

Shane Hamilton (corresponding author)

The York Management School, University of York

229 LMB, Freboys Lane

Heslington

York YO10 5GD

Shane.hamilton@york.ac.uk

+44 (0) 1904325305

KEYWORDS: strategic alliances, entrepreneurial partnering, comparative history, periodization, temporal structuring, poultry farming, agribusiness

\title{
Research Summary:
}

This comparative historical analysis demonstrates how memory and reflexive interpretations of the past can shape entrepreneurial willingness to collaborate with larger firms in an industry. Emphasizing the importance of spatial metaphors and periodization for developing historical knowledge, the paper focuses on how the historical space of experience explains how entrepreneurs make strategic choices regarding collaboration under conditions of complexity and uncertainty. Comparing the U.S. and U.K. emerging poultry sectors offers a methodologically novel analysis of an important but little-studied agribusiness sector, offering a dual reading that compares two versions of historical reasoning both theoretically and empirically.

\section{Managerial Summary:}

Historical experience matters to entrepreneurs, shaping their expectations about markets and opportunities, including possibilities for strategic alliances with larger firms. Rather than assuming that the events of the past structurally determine entrepreneurial expectations for the future, we demonstrate how experience, interpretation, and memory shape the nature of competition and collaboration in emerging industries. Our approach relies on the comparative method, suggesting a new way to consider how uses of the past might shape entrepreneurship in industries other than the U.S. and U.K. poultry industries that serve as our empirical focus. 


\section{INTRODUCTION}

History matters to entrepreneurs. Historical experience shapes their expectations about markets and opportunities (Popp and Holt, 2013; Wadhwani and Jones, 2014; Welter and Gartner, 2016). In moving from expectation to exploitation, entrepreneurs are typically constrained by significant resource gaps (Teng, 2007), and access to essential complementary resources often comes through strategic alliances. Yet scholars know little about whether or how history influences the propensity of entrepreneurs to develop or reject such partnerships.

Our research question is to explore whether and how historical experience impacts entrepreneurs' pursuit of strategic alliances. A lack of consensus among entrepreneurship scholars on how to explain the success or failure of strategic alliances suggests the need for more contextual analyses, including historical approaches. Yet recent research in strategic management has exposed the need for careful consideration of how history serves as both a structuring and a sensemaking element of strategy (Foster et al., 2017; Hatch and Schultz, 2017; Rowlinson, Hassard, and Decker, 2014; Suddaby, Foster, and Trank, 2010). For entrepreneurs, as with other organizational actors, the past is not an inert given but an experience, the interpretation of which shapes the present and sets expectations for the future (Wadhwani et al., 2018). How entrepreneurs perceive historical time thus becomes crucial for understanding the impact of the past on expectations for the present and future, including those regarding alliances. 
We propose two constructs - structure and space of experience-and argue that differences in their temporal dimensions can provide divergent explanations for entrepreneurial behavior. In doing so, we build upon Koselleck's (2004: 235) proposition that "time, as it is known, can only be expressed in spatial metaphors." What makes strategic sense in one spatial metaphor may not make sense in the other. As we demonstrate below, the structural historical approach most often deployed in strategy and entrepreneurship studies does not always explain why entrepreneurs make the choices they do. Uniting Koselleck's spatial metaphors for time with existing research in strategic uses of history, we call for increased attention to the ways in which entrepreneurs constitutively experience historical time (Kirsch, Moeen, and Wadhwani, 2014; Lippmann and Aldrich, 2016a; Suddaby and Foster, 2017; Vaara and Lamberg, 2016; Wadhwani, 2016a).

We articulate our argument by drawing on tools familiar to historians but uncommon in entrepreneurship studies: comparative history and periodization. We explain how attention to entrepreneurs' spaces of experience solves a puzzle, presented in a comparative case study, which is not fully answerable by a structural understanding of change over time. The case study explores the emergence and rapid growth of the modern poultry sector in the U.S. and the U.K. from 1920 to 1990, highlighting the similarities in technology and market structures in both national settings, but revealing a crucial difference in entrepreneurs' approaches to 
alliance formation. Different expectations, conditioned not by structures of the past but by interpreted experiences of the past, led to divergent approaches to alliances for the two groups of entrepreneurs.

\section{STRATEGIC ALLIANCES AND ENTREPRENEURIAL COLLABORATION}

Alliances present partners with opportunities to benefit from complementary assets.

The potential benefits are particularly acute in those settings with the greatest uncertainty - for instance, where entrepreneurial judgment is most required, or where technological change is rapid and the need to innovate is greatest (Godley, 2013; Godley and Casson, 2015; Jiang et al., 2016; Rothermael, 2001; Teng, 2007). Despite this strong incentive to cooperate, most alliances fail (Doz, 1996; Doz and Hamel 1998; Khanna, Gulati, and Nohria, 1998; Madhok, 2002; Milanov and Shepherd, 2013; Sarkar, Echambadi, and Harrison, 2001).

There is currently no consensus within the literature to explain why smaller entrepreneurial firms find alliance-based performance improvements to be elusive. One explanation of the high failure rates is that alliances with large firms leave small firms vulnerable to opportunistic exploitation (Baum, Calabrese, and Silverman, 2000; Dyer and Singh, 1998; Gulati, 1998; Lu and Beamish, 2006). Ariño, Ragozzino, and Reuer (2008), however, suggest that SMEs' reduced managerial capabilities rather than large firm opportunism better explains the failure of such alliances. Moreover, evidence that cooperative settings are essential preconditions for alliances 
to be successful is mixed. Some alliances are successful in non-cooperative settings, a result which questions the behavioral assumptions of alliance success (Kumar, 2010; Li et al., 2017; Shakeri and Radfar, 2017, Zhang et al., 2010).

Researchers trying to grapple with these sometimes contradictory results have suggested the need for more contextual analyses of entrepreneurs' strategic alliances, including longitudinal studies (Ariño et al., 2007; Jiang et al., 2016, Welter, 2011). In an important recent contribution, Li, et al. (2017: 47) suggest that researchers should distinguish between the 'behavioral and affective dimensions of an alliance relationship,' where the behavioral component describes partners' joint activities to accomplish tasks, whereas the affective dimension describes how the partners are bonded together through formal and informal links. Their survey results suggest that moderate levels of bonding between alliance partners support performance (Li et al., 2017). Yet it remains to be shown how historical experience might shape the context of affective bonding in alliances. Differing understandings of the past can produce divergent strategic responses to the business environment under conditions of complexity and uncertainty (Casson and Godley, 2005).

\section{STRUCTURE AND EXPLANATION}

There are multiple forms of historical knowledge which shape entrepreneurial strategies, although only a few have so far merited attention in entrepreneurship studies. Koselleck (2004) insists that historical knowledge can only be conveyed 
using spatial metaphors, for although chronological time proceeds linearly, human understandings of change over time are always contested, contingent, and multilayered. One spatial metaphor for the relationship between history, strategy, and entrepreneurship is structure. As a spatial metaphor for historical time, structure suggests that the past is composed of discrete components or building blocksevents - which can then be assembled into a linear, coherent history with defined contours. Thus as a spatial metaphor, structure proves especially useful for producing causal models for explaining change over time in linear terms.

For instance, patterns of integration within industries might be better explained using structural metaphors of change over time than by static approaches that define the boundaries of firms and markets solely in terms of transaction costs (Alvarez and Barney, 2005; Jacobides, 2005; Jacobides and Winter, 2005). Such approaches to industry architecture acknowledge the importance of change over time, but place a strong emphasis on the structural constraints that time's passage imposes on individuals and firms (Argyres and Bigelow, 2009; Fixson and Park, 2008; Jacobides, 2005; Pisano and Teece, 2007). Structure as a mode of historical understanding thus intentionally minimizes individual agency, seeking instead “higher-level causal forces that cannot be understood simply by looking at the level of individual agents" (Jacobides and Winter, 2012: 1366). 
The explanatory power of structural metaphors for historical time has proven strongest in evolutionary theory, path-dependency theory, and life-cycle theory (Argyres and Liebeskind, 1999; Arthur, 1989; David, 1985; David, 1992; Jack, Dodd, and Anderson, 2008). Yet with explanatory elegance comes the high cost of determinism. Constructing a linear history of an industry requires minimizing the agency of individuals and the contexts in which individual choices were madeincluding the prehistories of the people, firms, industries, and markets that may have influenced the paths eventually followed (Helfat and Lieberman, 2002; Sydow, Schreyögg, and Koch, 2009; Welter, 2011). Strong forms of evolutionary theory, for instance, demand a rejection of individuals exercising "prescient intentional action" to explain how organizations adapt to environments (Murmann, 2013: 59). For social scientists seeking to explain why an organization or industry has its present-day architecture, the causal mechanisms inherent to evolutionary, path-dependency, and life-cycle theory are useful modes of analysis that bear predictive weight. Yet the individuals who actually experienced the historical changes thus being explained might be surprised to learn that their actions had neither prescience nor intentionality.

\section{SPACE OF EXPERIENCE AND UNDERSTANDING}

An alternative spatial metaphor suggested by Koselleck (2004) is space of experience. Social scientists seeking clarity and elegance of explanation will not be likely to find comfort in the word space, which carries a dizzying array of connotations - including 
a period of time, a delimited physical area, a portion of a page of text, or a vast emptiness (OED Online, 2017). Yet for Koselleck the concept of the space of experience is useful as a metaphor for historical time precisely because of its imprecision, as an emptiness that is filled by the lived "experiences and expectations of active human agents," (2004: 231) with its outlines or delimiters put in place only through ongoing acts of interpretation of past events. By rejecting linear history we gain a richer understanding of how entrepreneurs faced the contingent, uncertain contexts of lived experience, and thus can come closer to understanding how those contexts shaped their ongoing strategic decisions (Anderson, Dodd, and Jack, 2012; Kaplan and Orlikowski, 2013; Kirsch et al., 2014; Lippmann and Aldrich, 2016a; Moroz and Hindle, 2011; Suarez, Grodal, and Gotsopoulos, 2015).

Imprinting theory and extended evolutionary theory have gained some traction in strategy and entrepreneurship literatures as modes of historical analysis that align with some aspects of the space of experience approach. Imprinting theory, first developed by Stinchcombe (1965) in application to organizations, has been shown to be useful for understanding how the early phases of organizational or industry development can have lasting, yet not necessarily deterministic, consequences over the long term (Johnson, 2007; Lippmann and Aldrich, 2016b; Marquis, 2003; Marquis and Tilcsik, 2013; Simsek, Fox, and Heavey, 2015). Extended evolutionary theory, alongside imprinting theory, seeks to allow for entrepreneurial agency in history both in the past, when making initial choices that may have long-term consequences, 
and in the present, when interpretations of past events may take on new meanings for shaping future decisions (Aldrich and Ruef, 2006; Aldrich and Yang, 2012; Forbes and Kirsch, 2011; Lippmann and Aldrich, 2014). In such views of entrepreneurial history, time is not linear but is instead like a set of punctuation marks, with the relationship between separate events not necessarily causal, and with each individual event potentially laden with significance and meaning (Dew, 2009).

Recent work in strategic management and organizational studies suggests the need for more work on how the space of experience can have significant consequences for firms and industries. History, as a conscious means of knowing rather than a passive accretion of past events, becomes a socially constitutive aspect of organizational behaviour (Suddaby, 2016; Wadhwani and Bucheli, 2014). Interpreting the past can enable managers to develop a coherent organizational identity, gain legitimacy in an emergent industry, and influence how organizational actors perceive strategic change (Anteby and Molnar, 2012; Dalpiaz and Di Stefano, 2017; Foster et al., 2017; Hatch and Schultz, 2017; Kirsch, 2000; Suddaby et al., 2010; Suddaby and Foster, 2017; Vaara, Sonenshein, and Boje, 2016; Zundel, Holt, and Popp, 2016). Yet despite rapid advances in empirical and theoretical research in strategic uses of the past, organizational scholars have not yet incorporated the full range of historical methods (Wadwhani et al., 2018). Periodization and comparative analysis in particular merit wider consideration. 


\section{PERIODIZATION AS STRATEGIC TEMPORAL STRUCTURING}

Marking out such distinctions between these two spatial metaphors suggests incommensurability, as if deductive, structural explanations cannot coexist with inductive, interpretive narrations of change over time (Ankersmit, 1994). Yet history is widely expected to offer both explanation and interpretation. Although rarely explicated, historians use periodization as a tool to draw out the insights from both structural and experiential spatial metaphors (Blix, 2006; Fear, 2014; Zerubavel, 2004). Periodization can be defined as "the interpretive process by which developments in the past are organized into coherent periods, eras, or epochs" (Wadhwani, 2016a: 69). Periodization should be understood as a specific form of what Orlikowski and Yates (2002) call temporal structuring: an approach to time that acknowledges the active roles people play in deciding how time works in their lives, yet places those actions within structural constraints that remain outside individual control. Temporal structuring thus refuses to accept that experienced time is either purely a deterministic phenomenon or solely a socially constructed perception; it is instead "both the medium and the outcome of people's recurrent practices" (Orlikowski and Yates, 2002: 685).

Periodization, as a subset of temporal structuring, is an essential tool for transforming the past into history, simultaneously explaining structural transformations over time and interpreting the meaning of those changes. One mode of periodization used regularly in the social sciences is temporal bracketing, a 
heuristic device for segmenting the flow of time into comparable units, built on an assumption that individuals' actions are simultaneously constrained by and constitutive of structures over time (Langley, 1999). Periodization is thus distinguished from the constant flow of chronological time by its insistence on the social construction of time (Rowlinson et al., 2014). Importantly, periodization is practiced not only by observers of the past (historians) but also by participants, such as by entrepreneurs drawing on previous experience to reduce uncertainty in the present (Wadhwani, 2016a). Understanding periodization as a subset of temporal structuring allows such insights to be integrated with findings in the organizational identity literature that highlight how the ongoing processes of actively interpreting the past interact dynamically with the structural conditions of the present (Chreim, 2005; Gioia, Schultz, and Corley, 2000; Ravasi and Schultz, 2006; Whetten, 2006).

\section{THE COMPARATIVE HISTORICAL METHOD AND DATA}

Returning to the research question, we explore whether experiential historical memory might offer a means of explaining differences in entrepreneurs' willingness to partner with larger firms. We focus on a comparative case study, the emerging poultry sectors in the U.S. and U.K. from 1920 to 1990. In both locations, poultry entrepreneurs' access to the market was governed by much larger, established firms: supermarkets. The two geographically separated sets of poultry entrepreneurs operated within broadly similar contexts in terms of technological change, competitive conditions, and market structures. Despite this similarity, one set of 
entrepreneurs embraced alliances with large supermarkets, while the other set did not.

We explore this question using the comparative historical method. The comparative method has a long lineage in economic and business history and historical sociology. Many of the paradigm-defining contributions to each discipline have emerged from studies using the comparative method. Douglass North's framing of the significance of institutions such as property rights and the influence of informal constraints emerged from a deep historical comparison of long-distance trading practices in England and Spain (North and Thomas, 1973). Alfred Chandler demonstrated the significance of professional management in his defining contribution to business history from a comparison of the largest 200 firms in the U.S., U.K., Germany, and Japan (Chandler, 1990). But there are important criticisms of the comparative historical method when it has been applied to large-scale, complex social systems (Mahoney, 2003).

The ideal-type of qualitative comparative research would share many similarities to quantitative comparative experimental methodologies, for example those used by medical researchers in randomized control drug trials. This approach is fundamentally positivist, establishing the dimensions of similarity within the case and, using the principle of causal inference, draws suitable conclusions from the observed differences. It requires large numbers of observations and properly 
controlling for all other potential moderating influences. Historians, by contrast, incorporate both realist and interpretivist approaches into their comparative method (Vaara and Lamberg, 2016). This is partly because historical data, whether archival, secondary, or from oral history sources, are almost always incomplete and biased in some way. But it is also because of the impossibility of genuinely controlling for all the potential moderating factors in comparative historical studies of complex social situations (Mahoney 2003).

Data problems can partly be overcome through deep immersion in the sources, the triangulation of the different sources, and the explicit recognition of the veracity of some sources being greater than others (Kipping, Wadhwani, and Bucheli, 2014; Wadhwani, 2016b; Zundel, Holt, and Popp, 2016). Experiment design is significantly improved when differences in the contextual settings are "controlled for" by minimizing the differences as much as possible in order to compensate for the inability to select true "control populations." An example of this more recent controlled comparative historical method is Godley's comparison of Jewish immigrant entrepreneurs in New York and London between 1880 and 1914 and their change in entrepreneurial behavior in the two locations as they adopted American and British cultural values (Godley, 2001). But despite attention to experiment design, this study was unable to control for all the potential moderating factors relevant to Jewish immigrant cultural assimilation, and so still transposed between interpretivist and realist approaches in its conclusions, albeit more carefully than 
business historians had done previously. This combination of both realist and interpretivist epistemologies within the comparative historical method is rarely explicated by historians. But, once stated, it suggests that this is an unusual yet potentially quite fruitful approach for entrepreneurship and organizational scholars to embrace (Vaara and Lamberg, 2016). We deploy this epistemological aspect of the comparative method below by explicitly contrasting two different approaches to historical knowledge, structural and space-of-experience.

The specific population selected for comparison in this article is the population of entrepreneurs in the poultry industries in the U.S. and the U.K. Our dataset includes a wide range of archival documents, government records, price and market data, and secondary historical works, which we use to map out the similarities and differences in the structure of the two industries. To explore the space of experience of the entrepreneurial groups, we rely on a rich set of oral histories. The experiences of U.K. poultry entrepreneurs were recounted in a series of ten oral history interviews undertaken in 2006 and 2010 by Andrew Godley, which have been deposited with the British Library Sound Archive. The experiences of U.S. poultry entrepreneurs were gathered by oral history researchers in the late 1980s; one set of 40 interviews was transcribed and deposited at the Shiloh Museum of Ozark History in Springdale, Arkansas, while another set of 23 interviews is held at the Richard P. Russell Library in Athens, Georgia. These oral histories, because of their inherent subjectivity, provide valuable insights into how individual and collective memories 
shaped, and were shaped by, entrepreneurial choices made in the past; they "breathe life into history" (Thompson, 2017: 14). Where appropriate we also draw on documents generated earlier in the twentieth century, such as legislative testimony, speeches, and letters and notes in trade journals, illustrating that later recollections of events were rooted in documented historical experience.

\section{FINDINGS}

The structure of the U.S. and U.K. poultry industries, 1920-1990

Chicken, eaten only rarely in America in the early twentieth century, was by the 1960s one of the country's most commonly consumed meats. Innovations in genetics and breeding, animal nutrition and protein science, and intensive confined rearing techniques after World War II enabled U.S. production of chickens to increase fourfold between 1945 and 1955 (Boyd, 2001; Corley and Godley, 2011; Horowitz, 2005; Striffler, 2005). Poultry entrepreneurs sensed opportunities for reorganization and consolidation, with animal feed and hatchery firms integrating forward into chicken rearing and processor-distributors integrating backwards through contract growing (Gisolfi, 2006; Striffler, 2005).

The British poultry industry likewise only took off after World War II. Total commercial production of poultry reared for meat grew from five million birds in 1953, to ten million in 1956, to 100 million in 1961, and to 202 million by 1967 (Hunt and Clark, 1967; National Union of Agricultural Workers, 1961; Sykes, 1956). 
Industry concentration increased with rapid efficiency gains, which allowed prices to fall, in contrast to rising prices among red meats (Hunt and Clark, 1967). As prices fell, demand soared. While British per capita meat consumption overall was static after 1953, the poultry share rose from one percent in 1955 to one quarter by 1990, similar to poultry's 30 percent share of meat consumption in the U.S.

The industry structures of the American and British poultry sectors followed remarkably similar trajectories as they emerged. The chronologies followed in the two national settings were not identical. But we are here more concerned with following the causal outlines of industry events in relation to market conditions and opportunities. So we have adopted a temporal bracketing approach, which permits the constitution of comparative units of analysis for the exploration and replication of theoretical ideas (Giddens, 1984; Langley, 1999). Despite the two industries emerging at different dates, our adoption of the temporal bracketing approach enables a comparison as the two industries followed largely similar trajectories. Year 1 in the U.S. industry's trajectory is 1946, and in the U.K. 1956. Here Year 1 marks not the pre-emergent beginnings of the industry but the start of significant integration. In the U.S., full embrace of integration began only after the first modern coccidiostats enabled indoor rearing at scale for the first time (Roy, 1966). In the U.K., the continuation of wartime rationing of animal feed put a brake on integration until after 1954. The first full year after the derationing of animal feed was 1956. Obviously there is some arbitrariness in choosing 1946 and 1956 as starting points 
for emergence, but this is outweighed by the usefulness of exposing the broad similarities and key differences in the two industries that follows from the temporal bracketing approach.

As shown in figures 1 and 2, broiler industry growth in output was faster in the U.S than in the U.K. in the emergent period spanning the first 15 years. This is not surprising given the bigger size of the U.S. market. Both industries, however, experienced similar price declines during their emergent periods. Concentration in the two countries' broiler industries likewise followed broadly similar patterns (see table 1), with both industries initially populated by many hundreds of independent, small producers then consolidating rapidly. Notably, the extent of concentration was markedly higher in the U.K.

\section{\{INSERT FIGURES 1 and 2 and TABLE 1 HERE\}}

In both countries, the periods of intensive industry consolidation coincided with the rise of large supermarket chains as the predominant buyers of broilers. In the late 1940s, the leading U.S. food retailer, A\&P, sponsored a "Chicken of Tomorrow" contest to encourage technological innovations in broiler mass production (Hamilton, 2018; Horowitz, 2004). In the postwar U.K., leading retailers likewise expected growing consumer demand for chicken. Alan Sainsbury, head of the eponymous food retailer, had already developed its British meat and dairy supply 
lines, especially through a longstanding trading relationship with Lloyd Maunder, a supplier based in Devon. This relationship precipitated a transformation of rearing in Devon as Lloyd Maunder incorporated U.S. technologies (Godley and Williams, 2009).

U.K. retailers, like Sainsbury's, formed alliances with entrepreneurial poultry producers because of one important consequence of the drive to expand rearing. Economies of scale meant flocks grew from the hundreds to the tens of thousands, and the retailers became increasingly agitated over supply fluctuations and price volatility. The U.S. industry was plagued by periods of glut, before price falls subsequently led to farmers and processors exiting and so to periods of undersupply (House Committee on Small Business, 1957). But through their strategic alliances within their supply chain, retailers in Britain were able to co-ordinate poultry production cycles to an extent that was unimagined in the U.S. British retailers depended on "regularity in supplies, ... steady prices to the consumer ... [and] consistency in quality" to market the novel product, claimed Sainsbury's Max Justice in his keynote to the inaugural broiler conference (Poultry Farmer, 1955).

By contrast, large American supermarket chains pursued cheap chicken through the exercise of market power, not collaboration with specific producers. Retail buyers purchased chickens on regional spot markets, pitting producers in one region against another in a constant push to drive down prices (House Committee on Small 
Business, 1957). With U.S. supermarkets operating at arms' length, coordination of the chicken supply chain in the 1950s and 1960s fell instead to the "integrators" feed dealers like Ralston-Purina and Jesse Jewell in Georgia and processordistributors like Tyson in Arkansas or Perdue in Delmarva (Hamilton, 2018).

Although the nature of the relationship between suppliers and buyers differed in the two countries, the structure of retailer concentration was remarkably similar in the first fifteen years of broiler industry emergence. Over the emergent period the market share of the four largest supermarket chains in the U.S. remained steady within a range of $20.0 \%$ to $21.7 \%$ in the years 1948 to 1963 (Joint Economic Committee, 1977). In the U.K., market share of the top five supermarkets increased from less than $10 \%$ in 1956 , to over $10 \%$ in 1965 , then to over $17 \%$ by 1971 (Bevan, 2005, p. 242). The two leading firms in the U.S., A\&P and Safeway, combined held $16.5 \%$ market share a decade after the broiler industry began significant integration (Mueller and Garoian, 1961), while in the U.K. Sainsbury and Tesco together held 10\% share in 1965 and 13\% in 1971 (nine and fifteen years respectively after the emergent period began) (Bevan, 2005, p. 242).

Despite these similarities in markets, technology, and industry structure in the two nations, there was one significant difference. In the U.S., poultry entrepreneurs shunned close collaboration with mass retailers, while in the U.K. the opposite occurred. By the 1980s, when both industries had matured beyond their emergent 
periods, this significant divergence in industry architecture had only grown. In the U.S. in the 1970s and 1980s, poultry firms created by entrepreneurs decades earlier, including Tyson Foods and Perdue Farms, effectively displaced mass retailers as the dominant players in the industry. By 1980, 50 percent of chicken bought in U.S. supermarkets carried a brand name, and that name in almost all cases was that of a processor-integrator, not a supermarket (Striffler, 2005). By contrast, in the U.K. by 1980 the leading six supermarkets dominated food supply, enjoying a 70 percent market share overall, even higher in poultry. Almost all of this was sold through the retailers' own brands by 1980, with few producer brands able to survive. Over sixty percent of this poultry meat was nevertheless supplied by the leading ten firms, all bar one of which had been among the poultry industry's pioneers of the late 1950s. The structure of the two countries' poultry sectors therefore followed remarkably similar trajectories over their respective emergent phases. There were small differences - the U.K. sector became a little more concentrated, the U.S. industry faced a slightly more concentrated food retail sector. But the major difference was not in structure but behavior. In the U.K. the leading poultry industry entrepreneurs capitalized on the strength of their strategic alliances with the leading retailers. In the U.S. they did not.

The space of experience of U.S. and U.K. poultry entrepreneurs, 1920-1990

The preceding section relied on statistics and temporal bracketing to outline the broadly similar structures of the U.S. and U.K. poultry industries. We turn now to 
the space of experience of the entrepreneurs who helped build those industries, using oral histories to examine how entrepreneurs thought about and remembered the strategic actions they undertook as the industry emerged, grew, and matured.

In American poultry there are three widely remembered founding narratives of the pre-emergence stage of the industry, all characterized by disaster and serendipity. In 1923, Cecile Steele of Delaware, who usually ordered 50 chicks to raise as egg-laying hens, accidentally ordered 500, a misfortune to which she responded by raising the chickens to sell for meat, supposedly singlehandedly launching the Delmarva broiler industry (Williams, 1998). John Tyson likewise attributed the emergence of the Arkansas poultry industry to sheer accident, claiming that his produce truck ran out of fuel near Springdale in 1936. Forced to rethink his business, he began hauling plentiful local poultry to distant cities (Tyson, 1987, p. 56). A tornado destroyed much of Gainesville, Georgia, in April 1936, an event that supposedly pushed Jesse Jewell to provide both feed and chicks on credit to wiped-out farmers, accidentally initiating an integrated model for debt-financed poultry production (Hudgins, 1964). In all of these founding narratives - which regionally took on the significance of myth in the 1940s, actively remembered into at least the 1980s - the theme of trauma, crisis, or devastation being overcome by entrepreneurial vision offered a means of making sense of an industry constantly beset by uncertainty and rapid technological change. 
Hard times, not statistics of steady growth in markets, emerge most clearly in collective memories of early participants in the U.S. poultry industry. The space of experience of the interwar farm crisis that racked places such as the upcountry South and the Delmarva peninsula in the 1920s and 1930s shaped a perception that the range of choices was very limited for most participants in the poultry marketplace. In Northwest Arkansas, memories of the collapse of both row cropping and orchard production in the 1920s and 1930s remained vivid. One entrepreneur interviewed in 1987 remembered that his neighbors "were willing to do most anything to make a living" (Lemley, 1987: 92). Another remembered responding to the demise of the Arkansas apple industry by using his "fruit trees for firewood to heat the chicken [shed]s with" (Ritter, 1987: 233). The broiler takeoff opened a path out of poverty for many at a time when "there was not much else to do in the dust bowl days" (Ritter, 1987: 275). Memories of poverty, desperation, and powerlessness were so deeply imprinted on the first generation of poultry pioneers that even during the comparatively good times of the 1950s, fatalism and mistrust permeated their understanding of how the market was structured (Brooks, 1987).

Such founding narratives shaped the responses of poultry entrepreneurs to the 1950s-60s period of growth and consolidation in the U.S. poultry industry. By the 1950s, the contract system pioneered by Jesse Jewell in Georgia became the norm throughout the industry, enabling the rapid adoption of technological breakthroughs in intensive rearing. The feed conversion ratio of U.S. chickens 
dropped from 2.9 to 2.1 between 1955 and 1975, while the number of days required to reach market weight declined from 73 to 56 in the same period (Boyd, 2001). Yet the original purpose of contracting was not technological innovation but a forced response to market uncertainty, as Don Tyson (John's son and successor) recalled:

We had tremendous market swings in those days [the 1950s]. And the thing that involved this industry was that at the beginning the individual farmer was responsible for the feed and chickens and then as the market swings got rougher and rougher, the ups were alright but the farmer couldn't stand the down ones. So the feed dealer, feed manufacturer, the hatchery guy started softening the downs. Well, to do that [the integrator] had to take some of the ups and well, we had, we got into what we call contract farming. (Tyson, 1987)

Those integrators who were able to grow large enough to "take some of the ups" while weathering periods of overproduction did not understand their relationship with chain retailers to be a close partnership. Indeed, supermarket buyers come across in the space of experience of poultry entrepreneurs as near-adversaries. Jesse Jewell, called before Congress in 1957 to testify on the causes of turmoil in poultry prices, pointed out that in any given week A\&P might order "250 truckloads" of chickens - but because it could purchase from any number of integrators in Connecticut, Delmarva, Georgia, or Arkansas, the supermarket chain effectively played the integrators off each other. "They [supermarket chain buyers] dictate to us," Jewell told the congressional committee. "It is a buyer's market, and they dictate 
to us when the shoe is on their foot, and they do the kicking, and when it is our market we do the kicking"' (House Committee on Small Business, 1957: 225).

U.K. poultry entrepreneurs, like their American counterparts, remembered the preemergence stage of their industry as a time of overcoming crisis, but in the British case that crisis was existential. The prospect of the German blockade during World War II was a genuine threat to the survival of the U.K., such was its dependence on imported food (Brassley, 2012). Policymakers introduced stringent food rationing to temper consumer demand, and imposed compulsory collaboration among producers and retailers to improve coordination and control. One of the individuals who oversaw wartime food policy was Alan Sainsbury, who served on several key Ministry of Food committees, helped introduce the rationing system, and oversaw the move to a collaborative supply system among private-sector producers (Butler, 1998).

Alan Sainsbury sought to adapt wartime compulsory co-operative behavior to the competitive markets of the mid-1950s. John Maunder (of Lloyd Maunder) recalled being summoned to Sainsbury's headquarters in London in 1956 along with a few other pioneer poultry producers (Godley and Williams, 2009), and being told:

$[W] e^{\prime}$ re going to organise the country into sectors. And Maunder, you can have the West Country, and Antony Fisher [Managing Director of Buxted Chicken, the market leader] you can have the South-east, ... And we just sat 
there and took this. This was marching orders. We were basically told 'Go home and organise it.' And that's what - we had nothing more than that. We literally had to go back and organise it.

Maunder, Buxted, and the other selected processors then recruited farmers to supply them. It was not straightforward, but the system spread:

[Y]ou had to go out and literally persuade farmers to invest in chicken houses, at a time when it was a relatively unknown and unproven thing. It gathered momentum, of course, in a matter of a strikingly short period of time - only a couple of years. It really gathered momentum, and people started to talk.... But in those early stages it was very strange. And to get a farmer to actually understand the fact that he had to do, he had to put these day-old chicks in when we wanted them put in, because it had to be on a programmed output style.

The network of alliance partners guaranteed revenues to its insider-entrepreneurs. It was a system that constrained competitive forces, and so privileged insiders, but at the enormous benefit of smoothing the returns to capital investment in new facilities, in what was a highly volatile trade (Sykes, 1963, pp. 12, 30-4).

In both national contexts, the pre-emergence stage was one of crisis and great uncertainty. The responses of the different populations to those crises were similarly remembered in triumphant terms, yet key to the U.S. experience was a memory of 
individualistic heroism, whereas in the U.K. memories centered on shared responsibilities for confronting the wartime crisis. In the emergent stage of the U.S. industry, entrepreneurs continued to make sense of their industry as one with few options other than scaling up production and driving down prices to gain entry to national markets. In the U.K. emergent stage, by contrast, entrepreneurs remembered collaborating with retailers to gain the trust of skeptical consumers by producing stable supplies of quality meat. The divergent historical understandings of the relationship between poultry entrepreneurs and major retailers continued through the growth and stability stages, as the collective memories of the two industries' early stages influenced expectations and so reinforced the two divergent patterns of behavior in otherwise very similar structural settings.

\section{ANALYSIS AND CONCLUSION}

A structural approach to history seeks to lay out a linear set of developments, with each stage in the process causally linked to that which follows. A structural periodization thus emphasizes how entrepreneurs, even as they make strategic choices, have those choices constrained by external structures.

Causation cannot always be explained, however, by assuming that history develops in a linear fashion. In our comparative account, several lines of causation are certainly clear from the pre-emergence to emergence and growth stages. Emergence of a meat-type poultry industry, for instance, occurred when entrepreneurs sensed 
opportunities for expanding production and seeking new markets. Yet structure did not determine how those entrepreneurs would approach alliances with major retailers.

By contrast with the structural approach to history, the space-of-experience metaphor seeks to open up the interior of lived history, the "black box" of change over time (Foster et al., 2017). Periodization from this perspective takes on a role as a sensemaking tool, a means of enriching understanding, more than a means for revealing linear causality in a deterministic sense. In the comparative cases of the U.S. and U.K. poultry industries, the periodization that emerges from oral histories is rich in details that defy conventional economic logic. The entrepreneurs who built the two nations' poultry industries had, in structural terms, broadly similar experiences, but their interpretations of which periods of time were most significant for the long-term trajectory of the industries highlighted dramatically different understandings of the norms of behavior between industry stakeholders.

The collective memories of poultry entrepreneurs clearly indicate a divergence in American and British understandings of the likely consequences of partnering with retailers. The generation of American poultry entrepreneurs who made chicken into big business in the U.S. shared a common cultural understanding, forged during the interwar farm crisis, that poultry production entailed extreme market uncertainty and unavoidably combative, hyper-competitive relationships with the mass retailers 
who provided crucial access to markets. By contrast, the initial preference for a collaborative but exclusive network of suppliers expressed by Alan Sainsbury in 1956 was taken up with alacrity by five poultry entrepreneurs who remembered the compulsory cooperation of wartime.

Periodization, as a temporal structuring device for both historians of entrepreneurship and for entrepreneurs as constitutive historicists, therefore enables an approach to history that navigates between the poles of deterministic causality and unconstrained individual agency (Orlikowski and Yates, 2002; Vaara and Lamberg, 2016; Wadhwani and Jones, 2014). Our framework, which draws on the comparative method to highlight the pitfalls of relying solely on structural metaphors to explain historical change, demonstrates the need to listen to entrepreneurs rendering their own ideas about the past. Structures develop over time and constrain power relations, yet attending to the space of experience of historical actors makes clear that entrepreneurs must always make choices, such as whether to collaborate with established firms to gain access to markets.

The individual microhistorical founding narratives analyzed above show that the entrepreneurs all vividly recalled some key 'trigger' event (Vaara and Lamberg, 2016; Lippmann and Aldrich, 2016b). These triggers, understood as founding events in a coherent period of experience from which to draw behavioral lessons in later contexts, were different. In the U.S., the triggers centered on individualistic 
responses to unforeseen problems that then became opportunities. In the U.K., the principal trigger was that one of the leading retailers selected individual early stage poultry entrepreneurs and offered to collaborate. The historical precedent of the shared experience of the enforced wartime collaboration in food supplies provided a framework for the alliance partners to understand how to behave as partners, reinforced by the fact that almost all the poultry industry pioneers had strong military backgrounds (Godley, 2014; Holroyd and Trelford, 1986). There was an obvious and powerful shared experience of bonding to give affective support to the collective endeavor (Li et al., 2017).

Drawing on a wider range of historical understanding and methodology, including the comparative method, therefore offers the ability to open up epistemological space for accepting the surprising and the serendipitous at the same time as recognizing the constraints of external forces. This article shows how using historical methods enables a richer understanding of how entrepreneurs choose to enter into strategic alliances, and so contributes to a specific unsettled question in the literature on strategic entrepreneurship. But through its more explicit articulation of spatial metaphors of historical time, temporal structuring as a means of understanding the strategic use of historical time, and exposing the rich possibilities available by pursuing comparative methods, the article also contributes to the developing theoretical and methodological sophistication among business historians, a development which will, we suspect, continue to offer fruitful contributions to 
contextual entrepreneurship studies. Further research drawing on comparative approaches to the space of experience could bring fresh perspectives to significant areas of entrepreneurial decision-making, such as modes of internationalization, selection of funding sources, or strategies for building reputation, all areas where history undoubtedly matters to entrepreneurs but in which entrepreneurship scholars have tended to rely primarily on structural explanations.

\section{ACKNOWLEDGMENTS}

Special thanks are due to David A. Kirsch, Christina Lubinski, Daniel Wadhwani, the anonymous referees, and the participants in the Copenhagen Business School paper development workshop on Historical Approaches to Entrepreneurship Theory \& Research.

\section{REFERENCES}

Aldrich H, Yang T. 2012. Lost in translation: cultural codes are not blueprints. Strategic Entrepreneurship Journal 6(1): 1-17.

Aldrich H, Ruef M. 2006. Organizations evolving, 2nd ed. Sage: London.

Alvarez SA, Barney JB. 2005. How do entrepreneurs organize firms under conditions of uncertainty? Journal of Management 31(5): 776-793.

Alvarez SA, Ireland RD, Reuer JJ. 2006. Entrepreneurship and strategic alliances. Journal of Business Venturing 21(4): 401-404.

Alvarez SA, Godley A, Wright M. 2014. Mark Casson, The Eentrepreneur at thirty: continued relevance? Strategic Entrepreneurship Journal 8(Jun.): 185-194. 
Anderson AR, Dodd SD, Jack SL. 2012. Entrepreneurship as connecting: some implications for theorising and practice. Management Decision 50(5): 958-971.

Ankersmit FR. 1994. History and tropology: The rise and fall of metaphor. University of California Press: Berkeley.

Anteby M, Molnár V. 2012. Collective memory meets organizational identity: remembering to forget in a firm's rhetorical history. Academy of Management Journal 55(3): 515-540.

Argyres NS, Bigelow L. 2009. Innovation, modularity, and vertical deintegration: evidence from the early U.S. auto industry. Organization Science 21(4): 842-853.

Argyres NS, Liebeskind JP. 1999. Contractual commitments, bargaining power, and governance inseparability: incorporating history into transaction cost theory. Academy of Management Review 24(1): 49-63.

Ariño A, Ragozzino R, Reuer JJ. 2008. Alliance dynamics for entrepreneurial firms. Journal of Management Studies 45(1): 147-168.

Arthur WB. 1989. Competing technologies, increasing returns, and lock-in by historical events. The Economic Journal 99(Mar.): 116-131.

Bevan J. 2006. Trolley wars: The battle of the supermarkets. Profile: London.

Blix G. 2006. Charting the 'transitional period': the emergence of modern time in the nineteenth century. History and Theory 45(1): 51-71.

Boyd W. 2001. Making meat: science, technology, and American poultry production. Technology and Culture 42(Oct.): 631-64.

Brassley P. 2012. International trade in agricultural products, 1935-1955. In War, Agriculture, and Food: Rural Europe from the 1930s to the 1950s, Brassley P, Segers Y, Van Molle L (eds). Routledge: London: 33-54.

Brooks DW. 1987. Oral history interview with Brian S. Wills. Part 1, cassette 231, OHBRO01A, D. W. Brooks Oral History Collection, Richard P. Russell Library, Athens, GA.

Butler R. 1998. Obituary: Lord Sainsbury. Independent. 26 Oct.

Casson M, Godley A. 2005. Entrepreneurship and historical explanation. In Entrepreneurship in Theory and History, Cassis Y, Minoglou IP (eds). Palgrave Macmillan: Basingstoke, UK: 25-60.

Chandler, AD. 1990. Scale and scope: The dynamics of industrial capitalism. Belknap Press: Cambridge, MA.

Chreim S. 2005. The continuity-change duality in narrative texts of organizational identity. Journal of Management Studies 43(2): 567-593.

Corley TAB, Godley A. 2011. The veterinary medicine industry in Britain in the twentieth century. Economic History Review 64(3: 832-54. 
Dalpiaz E, Di Stefano G. 2017. A universe of stories: mobilizing narrative practices during transformative change. Strategic Management Journal 39(3): 664-696.

David PA. 1985. Clio and the economics of QWERTY. American Economic Review 75(May): 332-337.

David PA. 1992. Heroes, herds, and hysteresis in technological history: Thomas Edison and the 'battle of the systems' reconsidered. Industrial and Corporate Change 1: 129-80.

Dew N. 2009. Serendipity in entrepreneurship. Organization Studies 30(Jul.): 735-753.

Doz YL. 1996. The evolution of cooperation in strategic alliances: initial conditions or learning processes? Strategic Management Journal 17(S1): 55-83.

Doz YL, Hamel G. 1998. Alliance advantage: The art of creating value through partnering. Harvard Business School: Boston.

Dyer JH, Singh H. 1998. The relational view: cooperative strategy and sources of interorganizational competitive advantage. Academy of Management Review 23(4): 660-679.

Fear J. 2014. Mining the past: historicizing organizational learning and change. In Organizations in Time: History, Theory, Methods, Bucheli M, Wadhwani D (eds). Oxford University Press: Oxford: 169-191.

Fixson SK, Park J. 2008. The power of integrality: linkages between product architecture, innovation, and industry structure. Research Policy 37(8): 12961316.

Forbes DP, Kirsch DA. 2011. The study of emerging industries: recognizing and responding to some central problems. Journal of Business Venturing 26(5): 589602.

Foss NJ, Klein PG. 2012. Organizing entrepreneurial judgment: A new approach to the firm. Cambridge University Press: Cambridge.

Foster WM, Coraiola DM, Suddaby R, Kroezen J, Chandler D. 2017. The strategic use of historical narratives: a theoretical framework. Business History 59(8): 11761200.

Gartner WB. 1988. 'Who is an entrepreneur?' is the wrong question. American Journal of Small Business 12(4): 11-32.

Giddens A. 1984. The constitution of society. University of California Press: Berkeley.

Gioia DA, Schultz M, Corley KG. 2000. Organizational identity, image and adaptive instability. Academy of Management Review 25(1): 63-81.

Gisolfi MR. 2006. From crop lien to contract farming: the roots of agribusiness in the American South, 1929-1939. Agricultural History 80(Spring): 167-89. 
Godley AC. 2001. Jewish immigrant entrepreneurship in New York and London 18801914: Enterprise and culture. Palgrave: Houndmills.

Godley AC. 2013. Entrepreneurial opportunities, implicit contracts and market making for complex consumer goods. Strategic Entrepreneurship Journal 7(4): 273-287.

Godley AC. 2014. The emergence of agribusiness in Europe and the development of the western European broiler chicken industry, 1945 to 1973. Agricultural History Review 62(2): 315-36.

Godley AC, Casson MC. 2015. 'Doctor, doctor...': entrepreneurial diagnosis and market making. Journal of Institutional Economics 11(3): 601-621.

Godley AC, Williams B. 2009. Democratizing luxury and the contentious 'invention of the technological chicken' in Britain. Business History Review 83(Summer): 267-290.

Gulati R. 1998. Alliances and networks. Strategic Management Journal 19(4): 293-317.

Gulati R, Singh H. 1998. The architecture of cooperation: managing coordination costs and appropriation concerns in strategic alliances. Administrative Science Quarterly 43(4): 781-814.

Hamel G. 1991. Competition for competence and interpartner learning within international strategic alliances. Strategic Management Journal 12(S1): 83-103.

Hamilton S. 2018. Supermarket USA: Food and power in the cold war farms race. Yale University Press: New Haven.

Hatch MJ, Schultz M. 2017. Toward a theory of using history authentically: historicizing in the Carlsberg group. Administrative Science Quarterly 62(4): 657-697.

Helfat CE, Lieberman MB. 2002. The birth of capabilities: market entry and the importance of pre-history. Industrial and Corporate Change 11(Aug.): 725-760.

Hite JM. 2005. Evolutionary processes and paths of relationally embedded network ties in emerging entrepreneurial firms. Entrepreneurship Theory and Practice 29(1): 113-144.

Holroyd P, Trelford M. 1986. The History of the National Institute of Poultry Husbandry. Harper Adams Agricultural College, Newport, Shropshire.

Horowitz R. 2004. Making the chicken of tomorrow: reworking poultry as commodities and as creatures, 1945-1990. In Industrializing Organisms: Introducing Evolutionary History, Schrepfer SR, Scranton P (eds). Routledge: New York: 215-35.

Horowitz R. 2005. Putting meat on the American table: Taste, technology, transformation. Johns Hopkins University Press: Baltimore. 
House Committee on Small Business. Problems in the Poultry Industry, Part 1, Hearings, 85th Cong., sess. 1, May 9, 10, 13, 1957.

Hudgins P. 1964. "Meet Jesse Jewell: Mr. Poultryman in Georgia," North Georgia Life, Nov. Box 40, Folder 18, Georgiana Vertical Files, General topical files, Hargrett Rare Manuscripts Library, Athens, GA.

Hunt KE, Clark KR. 1967. Poultry and eggs in Britain, 1966-1967. Agricultural Economics Research Institute, University of Oxford: Oxford.

Jack S, Dodd SD, Anderson AR. 2008. Change and the development of entrepreneurial networks over time: a processual perspective. Entrepreneurship and Regional Development 20(2): 125-159.

Jack S, Moult S, Anderson AR, Dodd SD. 2010. An entrepreneurial network evolving: patterns of change. International Small Business Journal 28(4): 315-337.

Jacobides MG. 2005. Industry change through vertical disintegration: how and why markets emerged in mortgage banking. Academy of Management Journal 48(3): 465-498.

Jacobides MG. 2006. The architecture and design of organizational capabilities. Industrial and Corporate Change 15(1): 151-171.

Jacobides MG, Knudsen T, Augier M. 2006. Benefiting from innovation: value creation, value appropriation and the role of industry architectures. Research Policy 35(8): 1200-1221.

Jacobides MG, Winter SG. 2005. The co-evolution of capabilities and transaction costs: explaining the institutional structure of production. Strategic Management Journal 26(5): 395-413.

Jacobides MG, Winter SG. 2012. Capabilities: structure, agency, and evolution. Organization Science 23(5): 1365-1381.

Jiang X, Yang Y, Pei Y, Wang G. 2016. Entrepreneurial orientation, strategic alliances, and firm performance: inside the black box. Long Range Planning 49(1): 103116.

Johnson V. 2007. What is organizational imprinting? cultural entrepreneurship in the founding of the Paris opera. American Journal of Sociology 113(Jul.): 97-127.

Joint Economic Committee. 1977. Prices and Profits of Leading Retail Food Chains, 1970-1974, Hearing, 95th Cong., 1st sess., Mar. 30, Apr. 5.

Kaplan S, Orlikowski WJ. 2013. Temporal work in strategy making. Organization Science 24(4): 965-995.

Khanna T, Gulati R, Nohria N. 1998. The dynamics of learning alliances: competition, cooperation, and relative scope. Strategic Management Journal 19(3): 193-210. 
Kipping M, Wadhwani D, Bucheli M. 2014. Analyzing and interpreting historical sources: a basic methodology. In Organizations in Time: History, Theory, Methods, Bucheli M, Wadhwani D (eds). Oxford University Press: Oxford: 305-329.

Kirsch DA. 2000. The electric vehicle and the burden of history. Rutgers University Press: New Brunswick.

Kirsch DA, Moeen M, Wadhwani D. 2014. Historicism and industry emergence: industry knowledge from pre-emergence to stylized fact. In Organizations in Time: History, Theory, Methods, Bucheli M, Wadhwani D (eds). Oxford University Press: Oxford: 217-240.

Koselleck R. 2004. Futures past: On the semantics of historical time. Columbia University Press: New York.

Kumar MVS. 2010. Are joint ventures positive sum games? the relative effects of cooperative and noncooperative behavior. Strategic Management Journal 32(1): $32-54$.

Langley A. 1999. Strategies for theorizing from process data. Academy of Management Review 24(4): 691-710.

Lemley, W. 1987. Oral history interview with Franklin Evarts. Volume 1, The Poultry Industry in Arkansas: An Oral History, Shiloh Museum of Ozark History, Springdale, AR.

Li L, Jiang F, Pei Y, Jiang N. 2017. Entrepreneurial orientation and strategic alliance success: the contingency role of relational factors. Journal of Business Research 72: 46-56.

Lippmann S, Aldrich H. 2014. History and evolutionary theory. In Organizations in Time: History, Theory, Methods, Bucheli M, Wadhwani D (eds). Oxford University Press: Oxford: 124-146.

Lippmann S, Aldrich H. 2016a. The temporal dimension of context. In A Research Agenda for Entrepreneurship and Context, Welter F, Gartner WB (eds). Edward Elgar: Cheltenham, UK: 54-64.

Lippmann S, Aldrich H. 2016b. A rolling stone gathers momentum: generational units, collective memory, and entrepreneurship. Academy of Management Review 41(4): 658-675.

Lu JW, Beamish PW. 2006. Partnering strategies and performance of SMEs' international joint ventures. Journal of Business Venturing 21(Jul.): 461-486.

Madhok A. 2002. Reassessing the fundamentals and beyond: Ronald Coase, the transaction cost and resource-based theories of the firm and the institutional structure of production. Strategic Management Journal 23(6): 535-550. 
Mahoney J. 2003. Knowledge accumulation in comparative historical research. In Comparative Historical Analysis in the Social Sciences, Mahoney J, Rueschemeyer D (eds). Cambridge University Press: Cambridge: 131-174.

Marquis C. 2003. The pressure of the past: network imprinting in intercorporate communities. Administrative Science Quarterly 48(Dec.): 655-689.

Marquis C, Tilcsik A. 2013. Imprinting: toward a multilevel theory. Academy of Management Annals 7(1: 193-243.

Milanov H, Shepherd DA. 2013. The importance of the first relationship: the ongoing influence of initial network on future status. Strategic Management Journal 34(6): 727-750.

Moroz PW, Hindle K. 2011. Entrepreneurship as a process: toward harmonizing multiple perspectives. Entrepreneurship Theory and Practice 36(4): 781-818.

Mueller WF, Garoian L. 1961. Changes in the market structure of grocery retailing. University of Wisconsin Press: Madison.

Murmann JP. 2013. The coevolution of industries and important features of their environments. Organization Science 24(1): 58-78.

National Union of Agricultural Workers. 1961. Leaflet on the broiler industry. National Union of Agricultural and Allied Workers Records, Museum of English Rural Life, Reading, UK.

North DC, Thomas RP. 1973. The rise of the western world: A new economic history. Cambridge University Press: Cambridge.

OED Online. 2017. Oxford University Press. OED Online. http://www.oed.com/view/Entry/10408.

Orlikowski WJ, Yates J. 2002. It's about time: temporal structuring in organizations. Organization Science 13(6): 684-700.

Pisano GP, Teece DJ. 2007. How to capture value from innovation: shaping intellectual property and industry architecture. California Management Review 50(1): 278-296.

Popp A, Holt R. 2013. The presence of entrepreneurial opportunity. Business History 55(1): 9-28.

Poultry Farmer. 1955. 10 Sept., p. 5.

Ravasi D, Schultz M. 2006. Responding to organizational identity threats: exploring the role of organizational culture. Academy of Management Journal 49(3): 433458.

Ritter, RC. 1987. Oral history interview with Franklin Evarts, Springdale, AR. Volume 2, The Poultry Industry in Arkansas: An Oral History, Shiloh Museum of Ozark History, Springdale, AR. 
Rothaermel FT. 2001. Incumbent's advantage through exploiting complementary assets via interfirm cooperation. Strategic Management Journal 22(6-7): 687-699.

Rowlinson M, Hassard J, Decker S. 2014. Research strategies for organizational history: a dialogue between historical theory and organization theory. Academy of Management Review 39(3): 250-274.

Roy EP. 1966. Effective competition and changing patterns in marketing broiler chickens. Journal of Farm Economics 48(3): 188-201.

Sarkar MB, Echambadi R, Harrison JS. 2001. Alliance entrepreneurship and firm market performance. Strategic Management Journal 22(Jun.): 701-711.

Shakeri R, Radfar R. 2017. Antecedents of strategic alliances performance in biopharmaceutical industry: a comprehensive model. Technological Forecasting and Social Change 122: 289-302.

Simsek Z, Fox BC, Heavey C. 2015. 'What's past is prologue': a framework, review, and future directions for organizational research on imprinting. Journal of Management 41(1): 288-317.

Stinchcombe AL. 1965. Social structure and organizations. In Handbook of Organizations, March JG (ed). Rand McNally and Company: Chicago: 142-193.

Striffler S. 2005. Chicken: The dangerous transformation of America's favorite food. Yale University Press: New Haven.

Suarez FF, Grodal S, Gotsopoulos A. 2015. Perfect timing? dominant category, dominant design, and the window of opportunity for firm entry. Strategic Management Journal 36(3): 437-448.

Suddaby, R. 2016. Toward a historical consciousness: following the historic turn in management thought. M@n@gement 19: 46-60

Suddaby, R, Foster WM. 2017. History and organizational change. Journal of Management 43(1): 19-38.

Suddaby R, Foster WM, Trank CQ. 2010. Rhetorical history as a source of competitive advantage. Advances in Strategic Management 27(Jul.): 147-173

Sydow J, Schreyögg G, Koch J. 2009. Organizational path dependence: opening the black box. Academy of Management Review 34(4): 689-709.

Sykes G. 1963. Poultry: a modern agribusiness. Crosby Lockwood \& Co.: London.

Teng B. 2007. Corporate entrepreneurship activities through strategic alliances: a resource-based approach toward competitive advantage. Journal of Management Studies 44(1): 119-142.

Thompson P. 2017. The voice of the past: Oral history, 4th ed. Oxford University Press: Oxford. 
Tyson D. 1987. Oral history interview with Franklin Evarts, Springdale, AR. Volume 1, The Poultry Industry in Arkansas: An Oral History, Shiloh Museum of Ozark History, Springdale, AR.

Vaara E, Lamberg, JA. 2016. Taking historical embeddedness seriously: Three historical approaches to advance strategy process and practice research. Academy of Management Review 41(4): 633-657.

Vaara E, Sonenshein S, Boje D. 2016. Narratives as sources of stability and change in organizations: approaches and directions for future research. Academy of Management Annals 10(1): 495-560.

Wadhwani D. 2016a. Entrepreneurship in historical context. In A Research Agenda for Entrepreneurship and Context, Welter F, Gartner WB (eds). Edward Elgar: Cheltenham, UK: 65-78.

Wadhwani D. 2016b. Historical methods for contextualizing entrepreneurship research. In A Research Agenda for Entrepreneurship and Context, Welter F, Gartner WB (eds). Edward Elgar: Cheltenham, UK: 134-145.

Wadhwani D, Bucheli M. 2014. The future of the past in management and organization studies. In Organizations in Time: History, Theory, Methods, Bucheli M, Wadhwani D (eds). Oxford University Press: Oxford: 3-30.

Wadhwani D, Jones G. 2014. Schumpeter's plea: historical reasoning in entrepreneurship theory and research. In Organizations in Time: History, Theory, Methods, Bucheli M, Wadhwani D (eds). Oxford University Press: Oxford: 192-216.

Wadhwani D, Mordhorst M, Suddaby R, Popp A. 2018. History as organizing: the uses of the past in organization studies. Organization Studies In Press: 1-21.

Welter F, Gartner WB, eds. 2016. A research agenda for entrepreneurship and context. Edward Elgar: Cheltenham, UK.

Welter F. 2011. Contextualizing entrepreneurship: conceptual challenges and ways forward. Entrepreneurship Theory and Practice 35(1): 165-184.

Whetten DA. 2006. Albert and Whetten revisited: strengthening the concept of OI. Journal of Management Inquiry 15(3): 219-234.

Williams WH. 1998. Delmarva's chicken industry: 75 years of progress. Delmarva Poultry Industry, Inc.: Georgetown, DE.

Zerubavel E. 2004. Time maps: Collective memory and the social shape of the past. University of Chicago Press: Chicago.

Zhang H, Shu C, Jiang X, Malter AJ. 2010. Managing knowledge for innovation: the role of cooperation, competition, and alliance nationality. Journal of International Marketing 18(4): 74-94. 
Zundel M, Holt R, Popp A. 2016. Using history in the creation of organizational identity. Management and Organizational History 11(2): 211-235. 
Figure 1: U.S. and U.K. broiler industry output (000s metric tonnes), years after initial industry organization

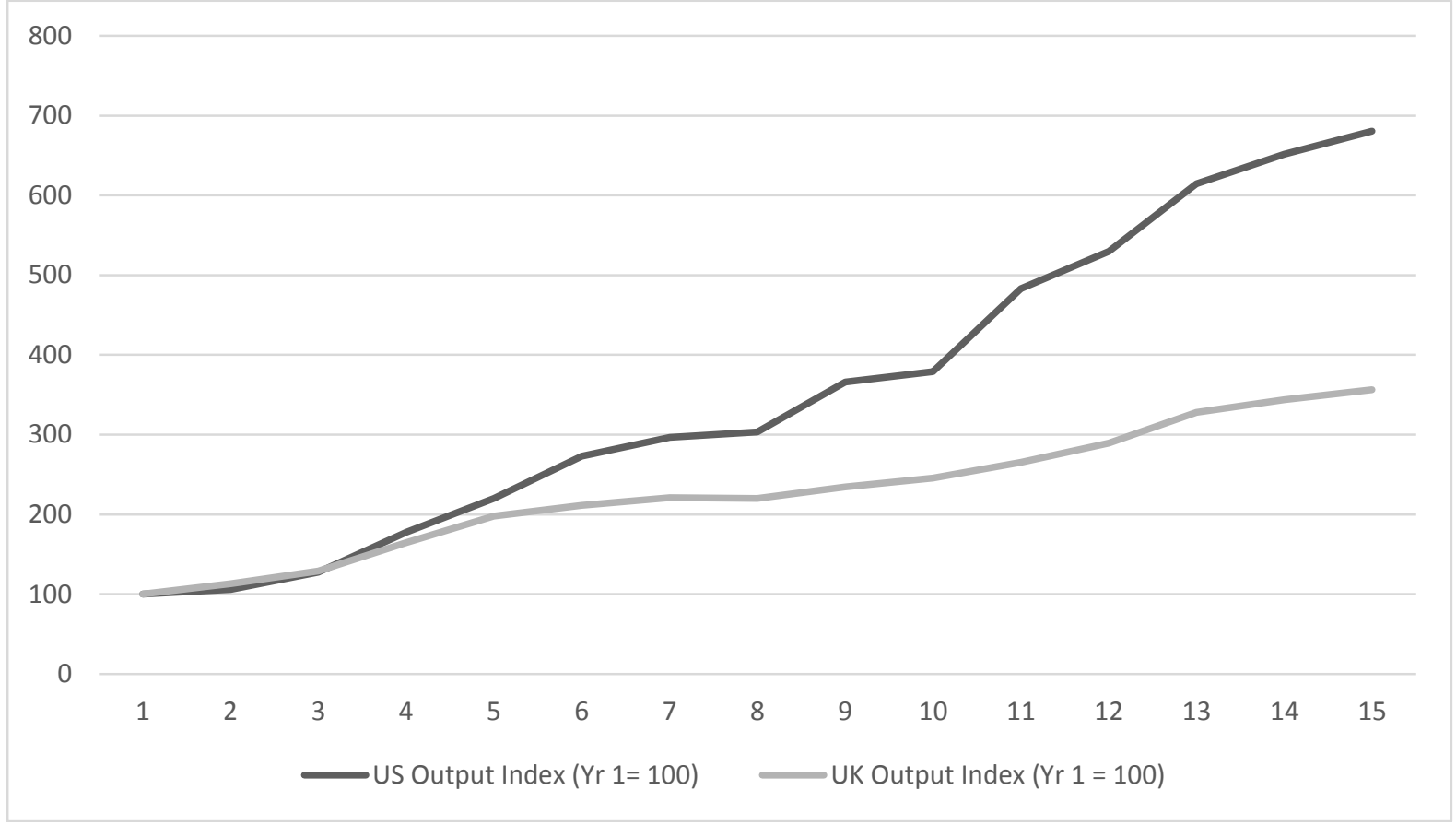

Sources: Godley, 2014; Roy, 1966. 
Figure 2: U.S. and U.K. broiler industry price declines, years after initial industry organization

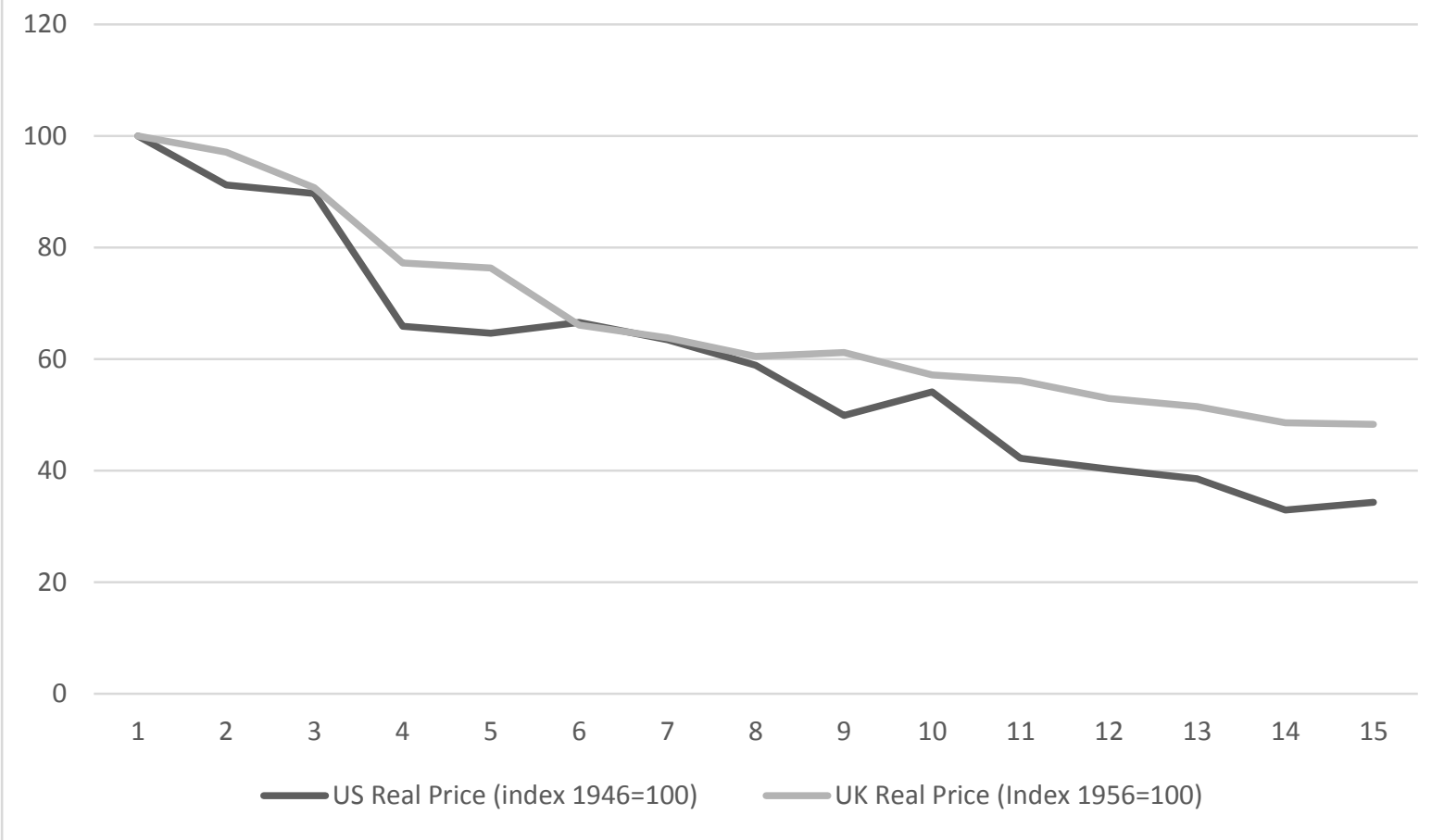

Sources: Hunt and Clark, 1967; Roy, 1966; US Inflation Calculator. 
Table 1: Concentration in U.S. and U.K. broiler industries, years after initial industry organization

\begin{tabular}{|l|l|l|}
\hline Years & U.S. Top 4 Market Share (\%) & U.K. Top 4 Market Share (\%) \\
\hline 1 to 3 & $<5$ & $<5$ \\
\hline 17 to 18 & 24 & 48 \\
\hline
\end{tabular}

Sources: Godley, 2014; Roy, 1966. 
DIFFERENT EXPECTATIONS 